\title{
Customer shopping experience using ahp weighted topsis method for selection of retail store in turkey
}

\author{
DOI: $10.46932 / \mathrm{sfjdv} 1 \mathrm{n} 3-009$
}

Received in: May 1st, 2020

Accepted in: June 30th, 2020

\author{
Mehmet Salih Goceri \\ $\mathrm{PhD}$ in Industrial Engineering Department from Istanbul University \\ Faculty at Santa Clara University \\ Address: Leavey School of Business, ISA Department, 500 El Camino Real Santa Clara, CA, 95117, \\ USA \\ E-mail: mgoceri@gmail.com
}

\begin{abstract}
In this paper, AHP-weighted TOPSIS has been used to select the best retail store in Turkey. 6 retail stores has been selected considering following factors; number of stores, annual revenue, and servicing area (being nationwide). The criteria for retail store selection have been found in a survey with 224 participants who described the important factors for their selection. 9 criteria have been determined as important factors for retail stores as follows: Price, advertising, cleanliness of market, quality of workers, support after sales, market layout design, promotions, brand image, time spending during shopping.

Moreover, a second survey is carried out with 212 people to find out the relative importance of these 9 criteria. The decision matrix and alternative weights of the criteria has been calculated in this way
\end{abstract}

Keywords: Customer Shopping Experience, Multi Criteria Decision Making, AHP, TOPSIS, Survey

\section{INTRODUCTION}

Customer shopping experience concept consist of many different criteria. Therefore, the selection of the retail store in a country is certainly a multi-faceted decision and many different customer behaviors and characteristics can be considered for the selection. However, the assessment of the selection is extremely difficult because of the complexity and multi-dimensionality of the shopping experience concept. In other words, the mixture of various socio-economic and environmental factors and some subjective perceptions of people increase the complexity of the decision.

In this study, the criteria for retail store selection process from customer shopping experience is based on a survey with 224 participants who described the important factors for their selection. Although there are many retail stores in Turkey, we have decided to choose 6 of retail stores considering following factors; number of stores, annual revenue, and servicing area (being nationwide). These 6 retail stores are distinctively being separated from the other retail stores based on these 3 factors. The criteria for retail store selection have been found in a survey with 224 participants who described the 
important factors for their selection. 9 criteria have been determined as important factors for retail stores as follows: Price, advertising, cleanliness of market, quality of workers, support after sales, market layout design, promotions, brand image, time spending during shopping. Moreover, a second survey is carried out with 212 people to find out the relative importance of these 9 criteria. The decision matrix and alternative weights of the criteria has been calculated in this way.

The best 6 retail stores listed in this study are denoted as A, B, C, D, E. and F. The weights of criteria have been calculated by using the AHP method.

6 expert opinions, from store managers, have been collected for the relative qualitative comparisons of the criteria. The weight of the criteria obtained by the AHP method is then used in the TOPSIS method for the final comparison of the 6 retail stores.

\section{LITERATURE REVIEW}

Multiple criteria decision-making (MCDM) is considered as a complex decision-making (DM) tool involving both quantitative and qualitative factors. In the literature, a great number of MCDM techniques and approaches have been suggested and applied to numerous different fields. To name some of these vast application areas, energy (Sengul et al., 2015), quality management (Lupo, 2015), supply chain management (Rajesh and Ravi, 2015), safety and risk management (Ilangkumaran et al., 2015), tourism management (Akincilar and Dagdeviren, 2014), production management (Rabbani et al., 2014), manufacturing technology and information management (Oztaysi, 2014) and supplier selection (Sevkli et al., 2007) can be listed.

AHP (Analytic Hierarchy Process) and TOPSIS (the Technique for Order of Preference by Similarity to Ideal Solution) are among the most common MCDM techniques.

AHP method, developed by Thomas L Saaty in the 1970s, is the most widely used MCDM method applied to extremely many different fields, either in the pure form or as a hybrid technique used with other methods. It is a widely used approach for obtaining preferences or weights of importance regarding to the criteria and alternatives for a variety of research fields. Some advantages of this method are the possibility of using qualitative as well as quantitative criteria, the ordered fashion of the decision making process which allows good traceability and the quality assurance obtained by the consistency indices (Saaty, 1988). Saaty has a study also on the most livable cities in United States (Saaty, 1986).

TOPSIS is used regularly as an MCDM method (Mardani et al, 2015) in a wide variety of fields. The main idea of the TOPSIS method came from the concept of the compromise solution to choose the best alternative nearest to the positive ideal solution (optimal solution) and farthest from the negative ideal solution (inferior solution) (Behzadian et al, 2012). In other words, the best alternative is the 
solution, which has the shortest distance to the ideal solution and the longest distance from the negative ideal solution (Hwang and Yoon, 1981). The ideal solution (also called positive ideal solution) is a solution that maximizes the benefit criteria/attributes and minimizes the cost criteria/attributes, whereas the negative ideal solution (also called anti-ideal solution) maximizes the cost criteria/attributes and minimizes the benefit criteria/attributes. The so-called benefit criteria/attributes are those for maximization, while the cost criteria/attributes are those for minimization.

In this study, a hybrid approach which uses both AHP and TOPSIS is proposed. The weights of criteria have been calculated by using the AHP method. Afterwards, TOPSIS method is used for the final comparison of the retail stores.

\subsection{AN USING AHP AND TOPSIS FOR THE SELECTION OF BEST RETAIL STORE}

The steps of AHP based TOPSIS method can be described as follows:

Step 1. Decision makers (DMs) who have experience regarding retail store selection process is defined. For AHP method, decision-makers (i.e. $\mathrm{D}_{1}, \mathrm{D}_{2}, \ldots, \mathrm{D}_{\mathrm{k}}$ ) decided the weight of each criteria by comparing each criterion (i.e. $\mathrm{C}_{1}, \mathrm{C}_{2}, \ldots, \mathrm{C}_{\mathrm{n}}$ ) . The importance averaged weights that obtained using AHP are given in Table 1.

Table 1 Weights for Criteria

\begin{tabular}{|c|c|c|c|c|c|c|c|c|}
\hline & Price & Advertising & $\begin{array}{c}\text { Cleanliness of } \\
\text { market }\end{array}$ & $\begin{array}{c}\text { Quality of } \\
\text { workers }\end{array}$ & $\begin{array}{c}\text { Customer } \\
\text { Support }\end{array}$ & $\begin{array}{c}\text { Market } \\
\text { layout } \\
\text { design }\end{array}$ & Promotions & $\begin{array}{c}\text { Spending } \\
\text { Brand } \\
\text { Image }\end{array}$ \\
\hline 0,11 & 0,4 & 0,12 & 0,10 & 0,10 & 0,9 & 0,17 & 0,20 & 0,06 \\
\hline
\end{tabular}

Step 2. A decision matrix has been composed using the second survey. A Likert scale of 5 is used.

Table 2 Decision Matrix

\begin{tabular}{|c|c|c|c|c|c|c|c|c|c|}
\hline & Price & Advertising & $\begin{array}{c}\text { Cleanliness of } \\
\text { market }\end{array}$ & $\begin{array}{l}\text { Quality of } \\
\text { workers }\end{array}$ & $\begin{array}{c}\text { Customer } \\
\text { Support }\end{array}$ & $\begin{array}{c}\text { Market } \\
\text { layout } \\
\text { design }\end{array}$ & Promotions & $\begin{array}{l}\text { Brand } \\
\text { Image }\end{array}$ & $\begin{array}{c}\text { Time } \\
\text { Spending } \\
\text { During } \\
\text { Shopping }\end{array}$ \\
\hline A & 3.37 & 2.25 & 4.55 & 4.23 & 3.96 & 3.46 & 2.84 & 2.90 & 3.30 \\
\hline $\mathrm{B}$ & 4.09 & 2.59 & 4.63 & 4.25 & 4.31 & 3.66 & 2.81 & 3.23 & 3.63 \\
\hline $\mathrm{C}$ & 3.21 & 2.22 & 4.16 & 4.42 & 3.21 & 3.26 & 2.39 & 2.88 & 3.74 \\
\hline $\mathrm{D}$ & 3.08 & 2.20 & 4.58 & 4.25 & 3.92 & 3.70 & 2.64 & 3.14 & 3.65 \\
\hline $\mathrm{E}$ & 3.86 & 2.05 & 4.75 & 4.48 & 4.19 & 4.01 & 2.65 & 3.24 & 3.55 \\
\hline $\mathrm{F}$ & 3.63 & 1.69 & 4.64 & 4.50 & 4.38 & 4.03 & 3.05 & 3.16 & 3.38 \\
\hline
\end{tabular}


Step 3. Normalization has been calculated as follows:

The decision matrix is $X=\left(x_{i j}\right)_{m \times n}$ and normalized criteria is $r_{i j}$

$$
r_{i j}=\frac{x_{i j}}{\sqrt{\sum_{i=1}^{m} x_{i j}^{2}}} \text { for maximization, where } i=1,2, \ldots, m \text { and } j=1,2, \ldots, n
$$

Table 3 Normalized Decision Matrix

\begin{tabular}{|c|c|c|c|c|c|c|c|c|c|}
\hline & & & Cleanliness & & & & Quality of \\
of market & Workers & $\begin{array}{c}\text { Customer } \\
\text { Support }\end{array}$ & $\begin{array}{c}\text { Market } \\
\text { layout } \\
\text { design }\end{array}$ & Promotions & $\begin{array}{c}\text { Time } \\
\text { Spending } \\
\text { Brand } \\
\text { Image }\end{array}$ \\
Shopping \\
\hline A & 0.39 & 0.42 & 0.41 & 0.40 & 0.40 & 0.38 & 0.42 & 0.38 & 0.38 \\
\hline B & 0.47 & 0.48 & 0.41 & 0.40 & 0.44 & 0.40 & 0.42 & 0.43 & 0.42 \\
\hline C & 0.37 & 0.42 & 0.37 & 0.41 & 0.33 & 0.36 & 0.36 & 0.38 & 0.43 \\
\hline D & 0.35 & 0.41 & 0.41 & 0.40 & 0.40 & 0.41 & 0.39 & 0.41 & 0.42 \\
\hline E & 0.44 & 0.38 & 0.43 & 0.42 & 0.43 & 0.44 & 0.40 & 0.43 & 0.41 \\
\hline F & 0.42 & 0.32 & 0.42 & 0.42 & 0.45 & 0.44 & 0.45 & 0.42 & 0.39 \\
\hline
\end{tabular}

Step 4. $V=\left(v_{i j}\right)_{m \times n}$ the weighted normalized decision matrix has been calculated as follows:

$$
v_{i j}=r_{i j} \cdot w_{j} \text { where } i=1,2, \ldots, m \text { and } j=1,2, \ldots, n
$$

where $w_{j}$ is the relative weight of the $j^{\text {th }}$ criterion obtained in Step 1 , and $\sum_{j=1}^{n} w_{j}=1$

After obtaining the normalized matrix, the weighted normalized decision matrix has been calculated using Equation 2 and shown below in Table 4. 
Table 4 Weighted Normalized Decision Matrix

\begin{tabular}{|c|c|c|c|c|c|c|c|c|c|}
\hline & Price & Advertising & $\begin{array}{c}\text { Cleanliness } \\
\text { of market }\end{array}$ & $\begin{array}{c}\text { Quality of } \\
\text { workers }\end{array}$ & $\begin{array}{c}\text { Customer } \\
\text { Support }\end{array}$ & $\begin{array}{l}\text { Market } \\
\text { layout } \\
\text { design }\end{array}$ & Promotions & $\begin{array}{l}\text { Brand } \\
\text { Image }\end{array}$ & $\begin{array}{c}\text { Time } \\
\text { Spending } \\
\text { During } \\
\text { Shopping }\end{array}$ \\
\hline A & 0.042 & 0.169 & 0.082 & 0.040 & 0.040 & 0.344 & 0.072 & 0.076 & 0.023 \\
\hline $\mathrm{B}$ & 0.052 & 0.193 & 0.083 & 0.040 & 0.044 & 0.364 & 0.071 & 0.085 & 0.025 \\
\hline $\mathrm{C}$ & 0.041 & 0.166 & 0.075 & 0.041 & 0.033 & 0.324 & 0.061 & 0.076 & 0.026 \\
\hline $\mathrm{D}$ & 0.039 & 0.165 & 0.082 & 0.040 & 0.040 & 0.367 & 0.067 & 0.083 & 0.025 \\
\hline $\mathrm{E}$ & 0.049 & 0.153 & 0.085 & 0.042 & 0.043 & 0.399 & 0.067 & 0.085 & 0.025 \\
\hline $\mathrm{F}$ & 0.046 & 0.126 & 0.083 & 0.042 & 0.045 & 0.400 & 0.077 & 0.083 & 0.023 \\
\hline
\end{tabular}

Step 5. The positive-ideal $\left(A^{*}\right)$ and negative-ideal $\left(A^{-}\right)$solutions has been determined using Equation 3 and 4.

$$
\begin{aligned}
& A^{*}=\left\{v_{1}^{*}, v_{2}^{*}, \ldots, v_{n}^{*}\right\} \text { where } v_{j}^{*}=\max _{i}\left(v_{i j}\right) \\
& A^{-}=\left\{v_{1}^{-}, v_{2}^{-}, \ldots, v_{n}^{-}\right\} \text {where } v_{j}^{-}=\min _{i}\left(v_{i j}\right)
\end{aligned}
$$

The Euclidean distances of each alternative from the positive-ideal solution and the negativeideal solution has been calculated as follows:

$$
\begin{array}{ll}
d_{i}^{*}=\sqrt{\sum_{j=1}^{n}\left(v_{i j}-v_{j}^{*}\right)^{2}} & i=1,2, \ldots, m \\
d_{i}^{-}=\sqrt{\sum_{j=1}^{n}\left(v_{i j}-v_{j}^{-}\right)^{2}} & i=1,2, \ldots, m
\end{array}
$$

The distance values can be shown in Table 5 .

Table 5 Euclidean Distance of each Alternative

\begin{tabular}{|c|c|c|}
\hline & $d_{i}^{*}$ & $d_{i}^{-}$ \\
\hline $\mathrm{A}$ & 0.0635 & 0.0494 \\
\hline $\mathrm{B}$ & 0.0371 & 0.0816 \\
\hline $\mathrm{C}$ & 0.0855 & 0.0402 \\
\hline $\mathrm{D}$ & 0.0474 & 0.0595 \\
\hline $\mathrm{E}$ & 0.0417 & 0.0819 \\
\hline $\mathrm{F}$ & 0.0675 & 0.0802 \\
\hline
\end{tabular}


Step 6: The relative closeness of each alternative to the ideal solution can be calculated as below. The relative closeness of the alternative $A_{i}$ with respect to $A^{*}$ is defined as $C C_{i}$

$$
C C_{i}=\frac{d_{i}^{-}}{d_{i}^{*}+d_{i}^{-}} \quad i=1,2, \ldots, m
$$

The bigger the $C C_{i}$, the better the alternative $A_{i}$. The best alternative is the one with the greatest relative closeness to the ideal solution.

Table 6 Relative closeness to the ideal solution.

\begin{tabular}{|c|c|}
\hline$A$ & 0.437441 \\
\hline$B$ & $\mathbf{0 . 6 8 7 3 5 2}$ \\
\hline C & 0.320103 \\
\hline$D$ & 0.556756 \\
\hline E & 0.662653 \\
\hline$F$ & 0.542931 \\
\hline
\end{tabular}

As seen above in Table 6, using the AHP-based TOPSIS method, retail store B has been determined as the best retail store.

\section{CONCLUSION}

In this study, an AHP based TOPSIS method is proposed for selecting the best retail stores from customer experience perspective in Turkey. The criteria used for the process are price, advertising, cleanliness of market, quality of workers, support after sales, market layout design, promotions, brand image, time spending during shopping.

For selecting the retail stores in Turkey, first the weights of the criteria were determined by AHP. Brand Image and Promotions have been found the most effective criteria. Afterwards, TOPSIS method is used for the final comparison of the stores in Turkey.

As a conclusion, using the AHP-based TOPSIS method, retail store B has been determined as the best retail store from customer experience perspective. 


\section{REFERENCES}

Akincilar, A., Dagdeviren, M. (2014), “A hybrid multi-criteria decision making model to evaluate hotel websites”, International Journal of Hospitality Management, 36, 263-271.

Behzadian, M., Khanmohammadi O.S., Yazdani, M., Ignatius, J. (2012), “A state-of the-art survey of TOPSIS applications", Expert Systems with Applications, 39, 13051-13069

Delgado, M., Verdegay, J.L., Vila, M.A. (1992), "Linguistic decision-making models", International Journal of Intelligent Systems 7, 479-492.

Hwang, C.L. and Yoon, K. (1981), Multiple Attribute Decision Making: Methods and Applications, Berlin: Springer.

Ilangkumaran, M., Karthikeyan, M., Ramachandran, T., Boopathiraja, M., \& Kirubakaran, B. (2015), "Risk analysis and warning rate of hot environment for foundry industry using hybrid MCDM technique", Safety Science, 72, 133-143.

Kaufmann, A., Gupta, M.M. (1991), Introduction to Fuzzy Arithmetic: Theory and Applications, Van Nostrand Reinhold, New York.

Lupo, T. (2015), "Fuzzy ServPerf model combined with ELECTRE III to comparatively evaluate service quality of international airports in Sicily", Journal of Air Transport Management, 42, 249-259.

Mardani, A.; Jusoh, A.; MD Nor, K.; Khalifah, Z.; Zakwan, N.; Valipour, A. (2015), "Multiple criteria decision-making techniques and their applications-A review of the literature from 2000 to 2014", Econ. Res.-Ekon. Istraž, 28, 516-571.

Rabbani, A., Zamani, M., Yazdani-Chamzini, A., \& Zavadskas, E. K. (2014), "Proposing a new integrated model based on sustainability balanced scorecard (SBSC) and MCDM approaches by using linguistic variables for the performance evaluation of oil producing companies", Expert Systems with Applications, 41, 7316-7327.

Rajesh, R., \& Ravi, V. (2015), "Supplier selection in resilient supply chains: A grey relational analysis approach", Journal of Cleaner Production, 86, 343-359.

Saaty, T.L. (1988), Multicriteria Decision Making: The Analytic Hierarchy Process; Planning, Priority Setting, Resource Allocation, 2nd ed.; McGraw-Hill: New York, NY, USA.

Saaty T.L. (1986), "Absolute and Relative Measurement with the AHP. The Most Livable Cities in the United States,” Socio-Economic Planning Sciences, Vol. 20, No. 6, pp. 327-331.

Sengul, U., Eren, M., Eslamian Shiraz, S., Gezder, V., \& Sengul, A. B. (2015). Fuzzy TOPSIS method for ranking renewable energy supply systems in Turkey. Renewable Energy, 75, 617-625.

Sevkli M., Koh S.C.L., Zaim S., Demirbag M., Tatoglu E. (2007), “An application of data envelopment analytic hierarchy process for supplier selection: a case study of BEKO in Turkey", International Journal of Production Research 45 (9), 1973-2003. 